\title{
O VALOR DA VERDADE SEGUNDO AS CONFISSÕES DE AGOSTINHO DE HIPONA
}

Janduí Evangelista de Oliveira ${ }^{1}$

Dr. Marcos Roberto Nunes Costa ${ }^{2}$

\section{RESUMO}

Mais do que um conceito, a verdade é para Agostinho aquilo que, por assim dizer, fundamenta sua própria subjetividade. Por meio de sua descoberta vemos uma grande transformação na vida do Bispo de Hipona: desde sua conversão ao cristianismo, bem como, o começo da sua atividade filosófica. Em vista disso, o presente trabalho procura mostrar e, ao mesmo tempo, analisar a busca de Agostinho por seu eu mais profundo que, em última medida, culminará com seu encontro com a verdade. Onde, a verdade vai se constituir como aquilo que ele encontrou depois de percorrer os caminhos mais diversos em sua vida pregressa. Para tanto, partimos das Confissões, obra na qual ele relata todo esse percurso, o que justifica nossa compreensão de que aqui essa questão é apresentada de forma mais consistente e amadurecida. Por outro lado, procuramos também, fazer uma ponte, vez ou outra, com as contribuições de alguns comentadores sobre a temática em questão.

Palavras-chave: Agostinho; Confissões; Verdade.

\section{Introdução}

A leitura das Confissões nos permite conhecer grande parte do extenso caminho percorrido por Agostinho em direção ao seu en mais profundo. Ao mesmo tempo, veremos que essa busca se dera antes mesmo de sua conversão ao Cristianismo, ocasião em que já experimentava uma vida carente de sentido, o que justificava sua vida desregrada e repleta de vaidades.

Foi precisamente esse sentimento que o motivou a fazer de sua vida uma intensa investigação acerca do sentido da vida humana, indo além do seu

1 Doutorando pelo Programa de Doutorado Integrado de Filosofia UFPE/UFPB/UFRN. Professor efetivo da Rede Estadual de Educação do Estado da Paraíba (desde 2012). Endereço para contato: janduiomi@hotmail.com

2 Doutor em Filosofia pela PUCRS, Pós-doutorado em Filosofia pela Universidade do Porto. Professor da Graduação e Pós-Graduação (Mestrado e Doutorado) em Filosofia da UFPE. E-mail: marcosnunescosta@hotmail.com 
problema particular, conforme comenta Josemar Bandeira de Souza:

Ele, na verdade, fez desse empreendimento algo muito maior que uma busca particular. Pelo contrário, longe de se ater aos limites de uma investigação pessoal, ele transpôs o limiar dos seus próprios interesses e em suas investigações procurou pela vida feliz entendendo-a sempre como finalidade da existência humana (2006, p. 12).

Nesse percurso, Agostinho foi entendendo que o bem que procurava deveria ser um bem não perecível, que realiza o homem perecível e imperfeito, um bem que vai além do mundo sensível e está mais próximo à interioridade do ser humano. Por isso, desde cedo, sua vida foi marcada por momentos de conflitos internos que influenciariam de forma negativa a sua personalidade.

No entanto, em meio a tudo isso, ainda na juventude, aconteceu o contato com a filosofia de Cícero, quando, em seus estudos, conheceu e leu a obra Hortênsio ${ }^{3}$, de Cícero. Nesse livro, o velho tribuno, desiludido das suas ambições políticas ${ }^{4}$, volta-se para a Filosofia, onde procura encontrar a felicidade na meditação das verdades eternas. Para tanto, percorrendo um caminho inverso, Cícero, falando pela boca de Hortênsio, o orador, fazia apologia à arte oratória e satirizava a Filosofia, enquanto seus interlocutores a defendiam. Porém, no final do diálogo, todos chegam à conclusão de que a Filosofia, ou contemplação intelectual, é superior à oratória, pois, pela elevação intelectual, o homem aproxima-se de Deus.

Ali, Agostinho encontrava a visão da bem-aventurança prometida aos

3 CAPÁNAGA, 1974, p. 9, faz uma relação entre o Hortensius de Cícero e o Protrepticode Aristóteles. Para ele, "O Hortensius, onde continha uma exortação à sabedoria; estava inspirado no Protreptico de Aristóteles”. Esse Livro, em forma de diálogo, hoje encontra-se perdido, e só conhecemos dele pequenos fragmentos, dentre os quais, os que Agostinho traz, citando-o em suas obras como, por exemplo, no tratado Sobre a Trindade: “Todos dizem que são felizes aqueles que vivem como querem. Mas isso é falso! Querer aquilo que não é digno do homem é, na verdade, a coisa mais miserável. E a infelicidade não consiste tanto em não se conseguir o que se deseja, mas muito mais em desejar e conseguir aquilo que nem sequer é digno de ser desejado"(De Trin., XIII, 5 ). Mas não só aí não é raro encontrarmos citações das mais variadas obras de Cícero nos escritos agostinianos, como, por exemplo, no diálogo Solilóquios: "A loucura dos insensatos é como o odor infecto da imundície: não é sentido, a não ser quando revolvidos"(Tusculanae, IV, 24,53, In: Sol., III, 11,19) e no diálogo Sobre a Vida Feliz; "Pense cada um o que quiser, quanto a mim, estimo que a frugalidade, isto é, a moderação ou temperança, é a mais excelente das virtudes"(Pro Deiotario, 26, In: De beat. vit., IV 31) e outros. Sobre a presença das obras de Cícero nos escritos agostinianos, recomendamos as obras específicas TESTARD, 1958a, 392 p. e Idem, 1958a, 142 p.

4 Segundo BARDY, 1940, p. 24 e CAPÁNAGA, 1954, p. 30, Cícero desiludiu-se da política depois da derrota de Pompeo, de quem havia sido partidário politicamente. 
que vivessem de acordo com a sabedoria, além da ideia, também, de que o conhecimento da verdade equivale ao conhecimento de Deus e de que a felicidade consiste na posse desse conhecimento, isto é, da verdade.Ademais, Cícero, como estóico, demonstrava que a oratória era o mais baixo degrau do $\mathrm{mal}^{5}$, e que os prazeres sexuais ofuscam o semblante do homem, impedindo-o de alcançar a verdade. Por isso, pregava uma moral ascética como instrumento purificador da alma, para se alcançarem as verdades intelectuais ou eternas.

As palavras de Cícero causaram verdadeira revolução no coração de Agostinho. Por isso, diz Guiovanni Papini,

já não se tratava mais de aguçar a fina ponta da linguagem e sim de elevar a inteligência; nem mais malabarizar palavras com o fito pecuniário e sim de pesquisar a sagrada verdade com todo o sacrifício; e nem de abaixar-se às impurezas do prazer, mas de buscar a Deus por meio da oração (1949, p. 42).

A partir do encantamento com o referido, suas ideias rasteiras e baixas se elevaram repentinamente, tomaram nova força e, como se fosse um milagre, despertaram-lhe o desprezo às coisas mundanas, a exemplo da fortuna, ambição, triunfos e até da glória. Doravante, Agostinho começa a pensar em Deus, como nos tempos de criança, quando vivia sob a viva influência de sua mãe.

5 Mais tarde, ao elaborar o Livro IV do tratado Sobre a Doutrina Cristã, intitulado "Sobre a Maneira de Ensinar a Doutrina", Agostinho iria servir-se largamente dos ensinamentos de Cícero, para denunciar o que ele ali chama de "oratória vazia", como, por exemplo: "O orador que exorbita numa eloquência sem sabedoria deve ser tanto mais evitado quanto mais os ouvintes sentem prazer ao ouvi-lo expor inutilidades [...]. Tal observação não escapou aos que julgavam outrora a eloquência dever ser ensinada. Reconheceram, com efeito, que a sabedoria sem eloquência foi pouco útil às cidades, mas, em troca, a eloquência sem sabedoria lhes foi frequentemente bastante nociva e nunca útil'"(De doct. christ., VI, 7). Aqui, para MARROU, 1938, p. 508-509, "Santo Agostinho mostra-se feliz de encontrar em Cícero condenação formal da eloquência enquanto um bem em si mesma". Para este, "legítima, quando ao serviço da verdade, a eloquência será condenável quando a serviço do erro". 


\section{O sentido da vida humana com base na verdade}

Para discutir essa questão, vamos diretamente as Confissões para ver o que Agostinho tem a dizer acerca da importância do Hortênsio para sua vida, principalmente num momento em que ele estudava eloquência tão somente com o intuito condenável e inútil de saborear os prazeres da vaidade humana:

Seguindo ao programa do curso, cheguei ao livro de Cícero, cuja linguagem, mais do que o coração, quase todos louvam. Esse livro contém uma exortação ao estudo da filosofia. Chama-se Hortênsio. Ele mudou o alvo das minhas afeições e encaminhou para Vós, Senhor, as minhas preces transformando as minhas aspirações e desejos (Conf. $\mathrm{I}, 3,4)$.

Em vista disso, segue-se a mudança de suas aspirações:as falsas esperanças tornaram-se desprezíveis e dão lugar a novos anseios. Tanto que, não era o estilo do Hortênsio que o atraia, mas tão somente o assunto tratado no Livroconforme ler-se: "Porém o amor da sabedoria, pelo qual aqueles estudos literários me apaixonavam tem o nome grego de filosofia" (Conf., I, 3, 4).

Nesse sentido, vale dizer que a filosofia ciceronianabuscava conciliar o estoicismo e com o epicurismo, em especial, no que concerne à questão da felicidade. Nesse sentido, o estoico defende que a felicidade está na independência do mundo exterior. Por isso, o sábio vive em harmonia com a razão e/ou natureza, colocando-a assim como pressuposto para a ataraxia. Desse modo, a virtude do sábio está na postura de indiferença perante o mundo, que se dá por meio do domínio da vontade e na decisão de aceitar o destino, o que culmina, assim, no desapego das coisas e aos homens.

No epicurismo, por outro lado, o prazer, é concebido como portador de sentido para a vida humana, quer dizer, se constitui como o Bem Supremo cujo modelo perfeito nos é fornecido pela vida dos deuses. No entanto, não confundir esse prazer como o prazer dos devassos, mas o prazer do sábio que o coloca sob o julgo da razão. Por isso, os prazeres são classificados nessa ótica: os naturais e necessários (os imprescindíveis para nossa existência: o prazer pela boa alimentação é um exemplo); os naturais e não necessários (os primeiros experimentos de forma exagerada, por exemplo, comer de forma desordenada); e os prazeres nem naturais nem necessários (o luxo, o poder, fama 
etc.). Portanto, diante de todos eles, o sábio rejeita os últimos e contenta-se com os primeiros, dado que é neles que se encontra o sentido da vida humana.

Como consequência do contato com o pensamento de Cícero, Agostinho, que admirava os bens temporais de forma exagerada, passa ressignificar vários aspectos da sua vida. Com relação a isso, escreve:

Apenas me deleitava, naquela exortação, o fato de essas palavras me exercitarem fortemente e acenderem em mim o desejo de amar, buscar, conquistar, reter e abraçar, não esta ou aquela seita, mas sim a própria sabedoria, qualquer que fosse (Conf., I, 3, 4).

Entretanto, o livro de Cícero teve o poder de despertar Agostinho do desânimo em que vivia, se mostrando assim, uma espécie de revelação, que o levou em direção à própria Verdade, conforme lê-se: “como ardia, Deus meu, como ardia em desejos do voar das coisas terrenas para Vós, sem saber como procedíeis comigo?" (Conf., I, 3, 4), foi o que levaria muitos comentadores a classificar como sua primeira conversão ${ }^{6}$. Entretanto, naquele momento, o famoso livro não foi capaz de trazer paz a seu coração inquieto, porque ao ler a obra de Cícero, Agostinho lamenta não ter encontrado nela o nome de Cristo: "Uma só coisa me magoava no meio de tão grande orador: não encontrar aí o nome de Cristo"(Conf., I, 3,4). Daí surge uma dúvida, se Agostinho ainda não se convertera ao Cristianismo, por que sentira falta do nome de Cristo no Hortênsio?

Em primeiro lugar, como bem observa Regis Jolivet ${ }^{7}$, não podemos nos esquecer de que Agostinho nasceu na fé, e por mais que tivesse se desviado moralmente da religião cristã, sua infância fora marcada pelas palavras de Cristo, pronunciadas pela boca de sua mãe, e tal fato reflete-se em seu

6 Cf. BROWN, 2005, p. 45, diz: "Por fim, no ano de 373, aos 19 anos, ele vivenciaria uma mudança profunda em sua vida: passaria por sua primeira 'conversão' religiosa'.

7 Falando sobre a eficácia que tiveram os primeiros ensinamentos cristãos de Mônica na vida de Agostinho, JOLIVET, 1932, p.11-12, diz: "Mônica [...], lhe falava da vida do Salvador e o ensinava a reverenciar o nome de Cristo. Deste modo, a fé cristã penetrou Agostinho até a medula, tanto que nada, nem as tempestades de sua adolescência, nem os sofismas maniqueus, nem as sutilezas da Nova Academia, puderam, jamais, arrancar de seu coração o convencimento de que Cristo era a fonte da salvação". 
sentimento, quando diz:

Porque este nome, segundo disposição de Vossa misericórdia, Senhor, este nome do meu Salvador e Filho Vosso, bebera-o com o leite materno o meu coração, e dele conservava o mais alto apreço (Conf., I, 3, 4).

Em segundo lugar, mesmo tendo se envolvido com uma série de atividades pagãs: teatros, circos, jogos etc., em Cartago, Agostinho filiou-se à Igreja Católica, ficando, de certa forma, fiel a sua tradição cristã, sendo, inclusive, aí que conheceu e se envolveu com sua amante ${ }^{8}$. Além do mais, devemos considerar que Agostinho viveu num século de grande efervescência do Cristianismo, que se apresentava sob a forma de "sabedoria-verdade", ou como uma filosofia. Tanto é assim que,

no século IV, nos meios intelectuais já não se cultuava mais a imagem do Cristo sofredor, crucificado e morto, mas a grandeza do Verbo de Deus, Sabedoria de Deus. E os sarcógrafos de Cristo desta época o representavam sempre na forma de um Mestre ensinando sua Sabedoria a um grupo de discípulos, como um Filósofo formando seus filósofos (BROWN, 2005, p. 50).

Portanto, de espírito marcadamente religioso, era natural que Agostinho fosse procurar na Bíblia esta "sabedoria-verdade", pois, a forma precisa de Sabedoria que Agostinho buscava conhecer era diferente daquela que Cícero tinha reconhecido como tal. Ou como nos diz o próprio Agostinho: "Tudo aquilo de que estivesse ausente este nome, ainda que fosse de uma obra literária burilada e verídica, nunca me arrebatava totalmente" (Conf., I, 3, 4). Esse fato levaria o comentador Michele F. Sciacca, a nos alertar que, "Agostinho não aderiu nunca a uma filosofia ou a uma doutrina sem Cristo, de quem, ainda criança, lhe havia falado Mônica, e que velava, inconscientemente, o dificílimo caminho de sua alma"(1955, p. 44)‥ Enfim, o

8Cf. BROWN, 2005, p. 50. BARDY, 1940, p. 25 é da mesma opinião, quando diz: "Em Cartago mesmo, nós sabemos, ele chegou váriasvezes a frequentar a Igreja". Estes comentadores fazem essas afirmativas a partir de uma pequena passagem das Confissões, que diz: "Até ousei nas cerimônias dos Vossos mistérios, dentro das paredes da Igreja, conceber um mau desejo e descobrir o meio para buscar os frutos da morte!”(Conf., III, 3).

9Aqui este comentador nos chama a atenção de que, não só agora, mas também mais tarde, após ler as obras neoplatônicas, Agostinho se volta para a Bíblia, quando descobriria os textos paulinos. Igualmente acentua BROWN, 2005, p. 50, quando diz: "Em uma época em que só os escritos dos adultos eram conservados, é muito difícil saber o que do cristianismo 'tradicional' 
certo é que a ausência do nome de Cristo no Hortênsio levou Agostinho a procurar as Sagradas Escrituras: "Determinei, por isso, dedicar-me ao estudo da Sagrada Escritura, para a conhecer" (Conf., I, 3, 5). E isso o deixou decepcionado. Mas o que teria decepcionado o jovem Agostinho na leitura das Sagradas Escrituras?

A resposta a essa questões, encontramos nas Confissões, quando ele diz apenas que diante da majestade da obra de Cícero a Bíblia pareceu-lhe indigna e modesta: "A sua simplicidade repugnava ao meu orgulho, e a luz da minha inteligência não lhe penetrava no íntimo" (Conf., I,3, 5) ${ }^{10}$. Entretanto, não devemos nos esquecer de que o Hortênsio o tinha despertado para o amor à filosofia como saber racional, daí, o que Agostinho procurava, naquele momento, nas Sagradas Escrituras, não era uma mensagem espiritual, fundada unicamente na fé, mas uma explicação científica (sabedoria-verdade) para os grandes problemas do $\operatorname{cosmos}^{11}$, especialmente, para o problema do mal, incluindo aí uma resposta para sua péssima conduta moral ${ }^{12}$. E isso, é evidente que não encontraria ali. Portanto, naquele momento, a Bíblia não satisfazia o coração inquieto de Agostinho. Tal hipótese é perfeitamente justificável quando lemos os escritos agostinianos antimaniqueus, onde há uma insistente defesa das Sagradas Escrituras, especialmente do Antigo Testamento, o mais atacado pelos Maniqueus. De tal sorte que, o que Agostinho não aceitou, naquele momento, foram as explicações bíblicas quanto às origens criacionistas

subsistia no espírito de um jovem homem como ele. Uma coisa pelo menos é certa: uma sabedoria onde o nome de Cristo estava ausente, era para ele absolutamente fora de questão". 10Para MARROU, 1938, p. 475-476, “a forma literária da Bíblia era certamente desconcertante para os letrados antigos, nutridos que estavam com a bela linguagem de Cícero e Virgílio [...]. A Bíblia parecia-lhes como livro estranho e grosseiro. Essa mesma impressão fora a de Agostinho adolescente e, antes dele, de Jerônimo, Arnóbio e Lactâncio”. BARDY, 1940, p. 26 é da mesma opinião, quando diz: "A velha Bíblia Latina foi traduzida numa linguagem popular, cheia de barbarismo e solepcismos". Entretanto, mais tarde, depois de convertido, Agostinho não admite que, no plano da cultura, a Bíblia seja considerada inferior às demais expressões literárias, como, por exemplo, no Livro IV, 6,7, de Sobre a Doutrina Cristã, onde procura demonstrar a beleza da forma literária da Bíblia.

11Esclarecendo o tipo de verdade que Agostinho buscava na Bíblia, diz BURGER, 1948, p. 41: "O que Agostinho entendia pelo nome de Verdade era o conhecimento filosófico do mundo criado, de suas causas segundas e de sua causa primeira. Aplicando aos dons dos sentidos a faculdade de abstrair e de generalizar que compreende a razão, ele tinha a intenção de remontar as coisas criadas ao seu autor, do múltiplo ao uno. Era uma reconstrução do mundo pela razão que Agostinho queria ver. Obra da razão, a Filosofia, tal qual os antigos a praticavam, engajava a alma inteira. Ela era assim uma religião. Um caminho que leva ao conhecimento de Deus, causa primeira e final, é religioso no fundo. Foi bem assim que Agostinho entendeu quando leu o Hortensius".

12A esse respeito diz BROWN, 2005, p. 57: "Somente esse grupo, julgou Agostinho, poderia responder à pergunta que começara a 'atormentá-lo' tão logo sua ‘conversão' à filosofia o levara a pensar com seriedade: 'qual é a causa de praticarmos o mal”'. 
do mundo (e do homem) e quanto à conduta moral dos patriarcas, que the pareciam destituídas de racionalidade científica, com aparentes contradições ético-morais, ou seja, ele não aceitou a falta de uma explicação para o problema do mal. Por isso, nos diz Gillian Evans,

a maior dificuldade de Agostinho em ler a Bíblia estava em aceitar o conteúdo do Antigo Testamento como digno de estudo sério. Não só na linguagem, mas também em sua descrição do comportamento de Abraão, Isaac, Jacó, Moisés e dos que vieram depois (1995, p. 28-29).

O certo é que, depois da leitura frustrada da Bíblia, na sua angústia e ânsia de encontrar a Verdade, Agostinho foi procurá-la na seita dos Maniqueus, como ele mesmo diz: "Caí assim nas mãos de homens orgulhosamente extravagantes, demasiado carnais e loquazes" (Conf., I, 3, 6), donde permaneceu porquase uma década. Não só entrou, mas tornou-se propagador da seita, chegando a levar consigo alguns de seus melhores amigos ou discípulos, bem como o seu mecenas Romaniano:

Durante este período de nove anos, desde os dezenove aos vinte e oito, cercado de minhas paixões, era seduzido e seduzia, era enganado e enganava: às claras, com as ciências a que chamam liberais, e às ocultas sob o falso nome de religião [...]. Seguia estas práticas, dandome a elas com meus amigos, iludidos por mim e comigo (Conf., I, 4, 1).

De acordo com Agostinho, os Maniqueus afirmavam falsamente sobre os mais diversos assuntos, desde a própria Verdade até os elementos deste mundo:

Ó Verdade, Verdade, pela qual intimamente suspiravam as fibras da minha alma, ainda mesmo quando eles frequentemente e de muitos modos te pronunciavam apenas com os lábios e te liam em muitos volumosos. As iguarias que me apresentavam, faminto da Vossa graça, eram, em vez de Vós, o sol e a lua, lindas obras Vossas, mas enfim obras Vossas e nunca Vós mesmo. Aquelas nem sequer são as primeiras da criação. Com efeito, as Vossas criaturas espirituais são superiores às corpóreas, ainda que estas se apresentem brilhantes e se movam no céu. Mas também não era dessas primeiras criaturas que eu andava faminto e sequioso, mas sim de Vós, de Vós, Verdade em que não há 'mudança nem sobra de vicissitude' (Conf., I, 3, 6). 
De um modo geral, os Maniqueus ensinavam que desde toda eternidade existem dois princípios: o do Bem e o do Mal. O primeiro, que se chama Deus, domina o reino da luz e Ele mesmo é luz imaculada, que só pela razão e não pelos sentidos se pode perceber. O segundo chama-se Satanás, rei das trevas; é mau quanto à sua natureza, pois é matéria infeccionada. Ambos comunicam a sua substância a outros seres, estes, por sua vez, são bons ou maus conforme a sua origem. Nessa doutrina, acredita-se que, no princípio, houve uma luta entre o reino da luz e o das trevas quando os demônios arrebataram partículas de luz. Com isso, Satanás gerou Adão e comunicou-lhe essas partículas, estas, por sua vez, seriam as almas dos homens. Então, para libertar a luz do cativeiro da matéria, Deus criou, por intermédio dos espíritos antagonistas dos demônios, o sol e a lua, os astros e a terra. Esta é constituída de matéria inteiramente corrompida.

Por seu turno, o homem é entendido como um conjunto de três substâncias: o corpo, oriundo do Mal; o espírito, que vem de Deus; e a alma insensível, cheia de maus apetites e dominada pelo mal. Todavia, para resolver o problema do mal, Deus teria enviado Cristo para salvar os homens, e ao Espírito Santo, menos que o Filho e também de substância puríssima, ficou a tarefa de agir beneficamente, contrariamente aos demônios, que só provocam calamidades. De um modo geral, a questão mais polêmica da doutrina maniqueísta era sobre a ressurreição de Cristo. Nesta, Cristo não teria tomado um corpo verdadeiro, mas aparente, e a conclusão que resulta, em última instância, é que sua morte não foi verdadeira.

Contudo, quanto mais Agostinho meditava, refletia e comparava as teorias maniqueístas acerca do mundo material e de toda a natureza acessível aos sentidos do corpo, ia concluindo que: "mais e mais me capacitava de que a maioria dos filósofos tivera opiniões muito mais prováveis" (Conf., I, 5, 14).

Dessa forma, à medida que seus conhecimentos sobre essa doutrina iam se ampliando, na mesma medida a convicção de que encontraria o que tanto procurava ia se dissolvendo, a ponto de Agostinho concluir: "afastava-me da verdade com a aparência de caminhar para ela, porque não sabia que o mal é apenas privação do bem, privação cujo último termo é o nada" (Conf., I, 3, 7). 
Logo, "as falsas opiniões que tinha dos seres espirituais não me deixavam vislumbrar a verdade. [...] Parecia-me que a alma racional e a essência da Verdade e do Soberano Bem residiam nessa unidade" (Conf., I, 4, 15).

Além disso, Agostinho observou também que os Maniqueus cometiam um erro metodológico ao anunciar a verdade:

Dizem muitas verdades acerca das criaturas e não buscam piedosamente a Verdade, o Artífice da criação. A consequência disso é que não $\mathrm{O}$ encontram; ou se $\mathrm{O}$ encontram não $\mathrm{O}$ honram como deviam nem lhe dão graças devidas. Em seus pensamentos se desvanecem, se dizem sábios e atribuem a si próprio o que é da verdade. Logo, convertem a verdade em mentira (Conf., I, 5, 3).

Com os Maniqueus de Roma, Agostinho conta que tinha o costume de juntar-se com os dirigentes que, por sua vez, se autodenominavam santos: “Não convivia somente com os 'discípulos' - em cujo número se contava o dono da casa em que eu adoecera e tivera a convalescença - mas, sobretudo frequentava o círculo dos chamados 'eleitos"' (Conf., I, 5, 10). Como resultado dessas experiências, o Bispo de Hipona percebeu a incompatibilidade dessa doutrina com a Verdadepor causa do determinismo inerente da doutrinamaniqueísta, o que, necessariamente traz implicação para a questão do livre arbítrio já defendido por Agostinho.

\begin{abstract}
Ainda então me parecia que não éramos nós que pecávamos, mas não sei que outra natureza, estabelecida em nós. A minha soberba deleitava-se com não ter as responsabilidades da culpa. Quando procedia mal, não confessava a minha culpabilidade, para que me pudésseis curar a alma, já que Vos tinha ofendido, mas gostava de a desculpar e de acusar uma outra coisa que estava comigo e que não era eu. $\mathrm{Na}$ verdade tudo aquilo era eu, se bem que a impiedade me tinha dividido contra mim mesmo! Era este pecado tanto mais difícil de cura, quanto eu mesmo menos pecador o julgava (Conf., I, 5, 10).
\end{abstract}

Todavia, o processo de afastamento da doutrina maniqueísta não ocorrera de modo repentino, pois, apesar das dúvidas, ele ainda conservava certa esperança de aí encontrar a Verdade. Desse modo, prosseguindo nessa doutrina com certa frouxidão e negligência. O que, de alguma medida, representavauma abertura de perspectiva para o entendimento da verdade, conforme se lê: 
Como eu tinha lido muitos filósofos e conservava na memória as suas teorias, comparava algumas delas com as longas fábulas dos maniqueístas. As doutrinas dos filósofos pareciam-me mais provável porque 'se mostraram com poder de avaliar o tempo presente, ainda que de modo algum encontrassem o seu Deus' (Conf., I, 5, 3).

A partir daí, o seu contato com os acadêmicos ${ }^{13}$ foi facilitadoao passo que Agostinho os considera muito mais prudentes que os Maniqueus, principalmente quando afirmam que tudo é passível de dúvida e nada de verdadeiro podia ser plenamente compreendido pelo homem. Portanto, o contato com os acadêmicos levou Agostinho a dá um passo a mais em direção à verdade, porque, embora não se fixando nessa corrente filosófica, ela permitiu que o Jovem Agostinho repensasse seu próprio modo de caminhar:

Ao meu espírito, que ainda não entendia tal doutrina, parecia que tinham raciocinado com esperteza, como vulgarmente se julgava. Não dissimulei em impugnar ao meu hospedeiro a sua demasiada crendice acerca das narrações fabulosas de que estavam cheios dos livros de Manés. Mas convivia com estes homens em mais estreita amizade do que com aqueles que não estavam infeccionados da heresia. Quanto a esta, já a não defendia com animosidade de outrora. Mas as relações amigáveis com maniqueístas - pois grande número deles se ocultava em Roma - tornavam-me bastante negligente em inquirir de outra coisa (Conf., I, 5, 10).

Embora considere as teorias dos Acadêmicos mais prudentes que dos maniqueus Agostinho não se limita a ela porque dado que a próprio comporta um grande impasse, pois, como levaradiante a investigação da verdade se se admite que ela não poderia ser compreendida plenamente pelo homem, conforme ensina a doutrina dos Acadêmicos? Ao mesmo tempo, Agostinho aponta par outra questão, a saber:

Porém, o principal e quase único motivo do meu erro inevitável era, quando desejava pensar no meu Deus, não poder formar uma ideia dele, se não lhe atribuísse um corpo, visto parecer-me impossível que houvesse alguma coisa que não fosse material (Conf., I, 5, 10).

13Os céticos 
Dessa forma, Agostinho continua sua busca pela verdade, mas, circunscrita no ceticismo, o que explica o fato de viver desconfiado de tudo e desanimado de encontrar a verdade, conforme se lê: "Para qualquer parte que se volte a alma humana é à dor que se agarra, se não se fixa em Vós, ainda mesmo que se agarre às belezas existentes fora de Vós e de si mesma" (Conf., I, 4, 10). Todavia, Agostinho ainda preservava a concepção pagã, adquirida nos filósofos romanos, que entende afilosofia como o porto da felicidade. Até mesmo depois de conversão, ele continuou atribuindo um valor positivo à filosofia pagã, conforme se lê:

Sabedoria e a ignorância são como os alimentos úteis ou nocivos. Podem-nos serem apresentados com palavras polidas ou com rudeza de forma, como os bons e maus alimentos nos podem ser servidos em pratos finos ou grosseiros (Conf., I, 5, 6).

Entretanto, a aproximação da filosofia não excluía por completo a influência dos vícios que se abatiam sobre a alma do Jovem Agostinho, porque, ainda residiam nela desejos e inclinações às honras e às riquezas. No entanto, em seu coração dizia:

\begin{abstract}
Admirava-me muito, ao recordar diligentemente quão longo fora o período de tempo decorrido após os dezenove anos, idade em que começara a arder no desejo da sabedoria propondo-me, depois de obtê-la, abandonar todas as esperanças frívolas e todas as loucuras enganosas das vãs paixões. Porém, chegado já aos trinta anos, continuava ainda preso ao mesmo lodo de gozar dos bens presentes que fugiam e me dissipavam (Conf., I, 6, 11).
\end{abstract}

Ainda que os caminhos que Agostinho percorreu até aqui não o terem conduzido à posse do que buscara, este se manteve firme e não permitiu que as vicissitudes da vida impedissem de continuar a sua procura pela verdade, haja vista que foi a partir delas que, certo dia, ele concluiu: "Pereça tudo isto e deixemos estas coisas vãs e fúteis. Entreguemo-nos unicamente à busca da verdade. A vida é miserável e a hora da morte incerta" (Conf., I, 6, 11). Entretanto, tal afirmação não nos autoriza afirmar que Agostinho seja indiferente ou ignore, ou ainda desconsidere, o valor desta vida, assim como combata a posse de bens materiais, como faziam os estóicos. Pelo contrário, pois o que há, neste caso, é uma reconsideração dos mesmos a um plano 
secundário:

[...] os bens terrenos também são agradáveis. Possuem não pequenas doçuras. Não devemos, por isso, apartar deles, inconsideravelmente, a nossa inclinação, pois seria vergonhoso voltar de novo a eles (Conf., I, $6,11)$.

Temos então, os últimos momentos dessa primeira fase da investigação do Hiponense porque buscar a verdade no mundo sensível passar a perder força mais força ainda, depois da leitura dos livros dos platônicos, em especial os de Plotino, quando Agostinho foi levado a buscar a verdade incorpórea, que por sinal, pode ser percebida nas perfeições invisíveis da Verdade no meio das coisas criadas. Nesse sentido temos,

Comecei a lê-los e notei que tudo o que de verdadeiro tinha lido nos livros dos platônicos se encontrava naqueles (Bíblia), mas com esta recomendação da Vossa graça: que aquele que vê não se glorie como se não tivesse recebido não somente o que vê, mas também a possibilidade de ver (Conf.,I, 7, 21).

Desde então, Agostinho inicia uma releitura dos textos bíblicos. Agora, de posse de uma visão mais crítica que os conhecimentos filosóficos lhe trouxeram, ele, que antes via de forma limitada, reiniciou o estudo dos textos bíblicos: "Estas coisas penetravam-me até as entranhas, por modos admiráveis, ao ler (São Paulo) 'o mínimo dos Vossos Apóstolos’. E enchia-me de espanto, considerando as Vossas obras..." (Conf., I, 7, 21).

Consequentemente, essa nova apreciação da Bíblia provocou uma transformação do jeito que Agostinho compreendea sua vida. Culminando então com a conclusão de que a vida na Verdade é única solução dos seus problemas:

tudo vacilava, porém, na minha vida temporal e o meu coração precisava de ser limpo do antigo fermento. O verdadeiro caminho, que é o Salvador, encantava-me, mas ainda me repugnava enveredar por seus estreitos desfiladeiros (Conf., I, 8, 1).

Consequentemente, nasce uma série de momentos de conflitos que, em alguns casos, compartilhava com seu amigo Simpliciano, um sacerdote muito instruído que viera a Milão para formar Ambrósio nas Sagradas Escrituras. 
Embora tivesse grande consideração por esse sacerdote, por outras vezes, Agostinho guardava para si suas dúvidas e tentava encontrar sozinho suas respectivas respostas. Em certa ocasião, diria o Bispo de Hipona:

A vontade nova que começava a existir em mim, a vontade de Vos honrar gratuitamente e de querer gozar de Vós, ó meu Deus, único contentamento seguro, ainda não se achava apta para superar a outra vontade, fortificada pela concupiscência. Assim, as duas vontades, uma concupiscente, outra dominada, uma carnal e outra espiritual, batalhavam mutuamente em mim. Discordando, dilaceravam-me a alma (Conf., I, 8, 5).

Paralelamente a isso, Agostinho recordou que já haviam decorrido aproximadamente uns 12 anos desde o momento em que se apaixonara pelo estudo da sabedoria quando da leitura do Hortênsio de Cícerorealizada aos 19 anos de idade:

Eu ia adiando a hora de desprezar a felicidade terrena, para me entregar à busca da Sabedoria, cuja investigação, para não falar já da sua descoberta, se deve antepor aos tesouros encontrados, aos reinos do mundo e enfim aos prazeres corporais que, a um aceno, afluíam à minha volta (Conf., I, 8, 7).

Desse modo, Agostinho concluiu que não iria encontrar a verdade no lugar onde a buscara, mesmo que ele tivesse cultivado a esperança de encontrála ali. Observou ele ainda que, nesse processo, era preciso deixar para trás a vaidade, porque ela só veio a prejudicar sua alma, por meio do ensurdecimento do ouvido e do coração, ficando ele desse modo, impedido de ouvir a voz da verdade. "O lugar do descanso imperturbável está onde o Amor não é abandonado, a não ser que o Amor nos abandone primeiro" (Conf., I, 4, 11).

Apesar disso, Agostinho permanecia indeciso frente às doutrinas que conhecera até o ponto de abandonar os maniqueístas, após nove anos de frequência às suas reuniões. Entretanto, ele se recusava terminantemente a confiar na cura das enfermidades de alma por meio dos Acadêmicos que, segundo sua opinião, desconheciam o nome de Cristo.

$\mathrm{Na}$ busca da verdade, o encontro com Santo Ambrósio, então Bispo de Milão, foi sem dúvida o mais determinante de todos. Este se deu quando o prefeito de Milão solicitou a Roma o envio de um professor de retórica, a quem seria concedida a licença para viajar representando a cidade. Nessa 
ocasião, Agostinho, ainda movido pela vaidade, solicitou esse emprego e, depois da seleção feita por Símaco, então prefeito de Roma, foi aprovado e enviado a Milão em 384:

Chegado a Milão, fui visitar o Bispo Ambrósio, conhecido pelas suas qualidades em toda terra e vosso piedoso servidor, cuja eloquência zelosamente servia ao Vosso povo 'a fina flor do Vosso trigo, a alegria do azeite de oliveira e a sóbria embriaguez do vinho'. Vós me leváveis a Ambrósio, sem eu e o saber, para ser por ele conscientemente levado a Vós (Conf., I, 5, 13).

Desde então, acentuou-se em Agostinho a intensão de firmar sua vida sobre uma base mais sólida e, ao mesmo tempo em que ia se convencendo de que somente na segurança da verdade é que seria possível encontrar-se consigo mesmo: "Eu ainda não gemia por Vós, ao rezar, para que me acudísseis, mas meu espírito estava inclinado a procurar-Vos e inquieto por discutir" (Conf., I, $6,3)$. Com isso, suas angústias pouco a pouco desapareciam e a luz da verdade começa a clarear a sua mente: "Assim o olhar, já mais purificado, da minha inteligência, dirigir-se-ia, de algum modo, para a Vossa verdade sempre constante e indefectível" (Conf., I, 6, 4).

É pertinente ainda destacar que Agostinho parece está convencido de que a razão sozinha não é capaz de oferecer o conhecimento pleno da verdade que sempre buscou. Nesse sentido, temos: "E assim, apesar de estarmos doentes para alcançar a verdade com a transparência da razão e por isso nos ser necessária a autoridade dos Livros Santos" (Conf., I, 6, 5). No caminho para a verdade Agostinho destacamos um fato que lhe ocorreu num bairro de Milão quando ele caminhava com seus amigos e na ocasião, ao avistar um pobre mendigo, ébrio, humorístico e alegre comentou com eles sobre o desejo de chegar à alegria segura, onde já tinha chegado aquele mendigo e onde talvez eles nunca chegassem:

Não possuía o ébrio, é certo, a alegria verdadeira. Mas, com tais ambições, eu buscava muito mais falsamente. Ele, com certeza, andava alegre e eu preocupado; ele vivia seguro e eu cheio de inquietações. Se alguém me perguntasse se eu preferia andar alegre ou perturbado, responderia: andar alegre. Se, porém, de novo me interrogasse se antes queria ser com o ébrio ou como eu era, escolheria viver acabrunhado por cuidados e temores (Conf., I, 6, 6).

Nota-se, desse modo, um Agostinho ainda muito distante do seu eu 
mais profundo, alguém cheio de angústia, mesmo já tendo adquirido a consciência da existência da verdade:

Importa saber a razão por que cada um se alegra. Conheço e vejo que a alegria da esperança fiel dita infinitamente daquela vaidade! Também entre o ébrio e mim havia grande diferença. Sem dúvida, ele era mais feliz não só porque transbordava de hilaridade - porém eu era devorado por ansiedades - mas porque ele adquiria o vinho desejando prosperidades aos seus benfeitores, enquanto eu procurava a ostentação com mentira (Conf., I, 6, 6).

Não é atoa que, por diversas vezes, Agostinho repetias essas coisas para seus amigos, a fim de que, juntamente com ele, pudessem examinar o que ocorria em suas vidas.Dado que o Bispo de Hipona continuava angustiado por encontrar-se consigo mesmo. "Se me sorria alguma ventura, sentia náuseas em apanhá-la porque ela voava no mesmo instante em que a ia agarrar" (Conf., I, 6, 6).

\section{Considerações finais}

Por fim, frente aos altos e baixos de sua vida, Agostinho chegou à conclusão de que somente algo que estivesse isento das vicissitudes da vida poderia corresponder às suas expectativas, pois, a verdade que tanto buscava só podia advir de algo atemporal e que não estivesse sujeito à corrupção. Tais comprovações tornam-se, assim, conteúdo constante de suas reflexões: "Revolvia tudo isso dentro do meu peito miserável, oprimido pelos mordazes cuidados do temor da morte e por não ter encontrado a verdade" (Conf., I, 7, 5). Em uma ocasião dessas, ele afirma que: "Aconselhado a voltar a mim mesmo, recolhi-me ao coração, conduzido por Vós. Pude fazê-lo, porque Vos tornastes meu auxílio" (Conf., I, 7, 10).

Esses momentos de autorreflexão foram comuns na vida do Bispo de Hipona, no entanto, um deles merece destaque:

Quando por uma análise profunda, arranquei do mais íntimo toda minha miséria e a reuni perante a vista do meu coração, levantou-se enorme tempestade que arrastou consigo uma chuva torrencial de lágrimas (Conf., I, 8, 12).

Conta Agostinho que os seus olhos brotaram rios de lágrimas, que iam 
se misturando à satisfação que o momento lhe trazia, entre falas, choro e desabafos.

Eis que, de súbito, ouço uma voz vinda da casa próxima. Não sei se era de menino, se de menina. Cantava e repetia frequentes vezes: 'Toma e lé; toma e lể [...] reprimi o ímpeto das lágrimas e levantei-me persuadindo-me que Deus só me mandava uma coisa: abrir o códice (Epistolas de S. Paulo) e ler o primeiro capítulo que encontrasse (Conf., I, 8, 12).

Estremecido e angustiado com tal acontecimento, Agostinho encontrou a resposta que procurava no livro das Epístolas dos Apóstolos que lhe dava a seguinte orientação:

Não caminheis em glutonarias e embriaguez, nem em desonestidades e dissoluções, nem em contendas e rixas; mas revesti-vos do Senhor Jesus Cristo e não procureis a satisfação da carne com seus apetites (BÍBLIA apud Conf., I, 8, 12) ${ }^{14}$.

A esse respeito, ele escreve ainda:

Não quis ler mais, nem era necessário. Apenas acabei de ler estas frases, penetrou-me no coração uma espécie de luz serena, e todas as trevas da dúvida fugiram. Então, marcando a passagem com o dedo ou com outro sinal qualquer, fechei o livro (Conf., I, 8, 12).

Eis, então, a ocasião de sua conversão, fato que marca profundamente o encontro consigo mesmo, porque é a partir dela que se torna possível a aquisição, com base na Verdade, das respostas aos seus questionamentos. Portanto, foi somente a partir de sua conversão que o Bispo de Hipona encontrou definitivamente a verdade o que, por sua vez, acarretará, necessariamente, a posse do seu verdadeiro eu.

\section{Referências}

AgOSTINHO, Santo. A doutrina cristã. Trad. de Nair de Assis Oliveira. São Paulo: Paulus, 2002. 284 p.

- A Trindade. Trad. e introd. de Augustino Belmonte. Rev. e notas compl. de Nair de Assis Oliveira. São Paulo: Paulus. 1994. 735p.

14Rm, 13, 13 
. Solilóquios; A vida feliz. 3. ed. Trad., introd. e notas de Adaury Fiorotti, Nair de Assis Oliveira e Roque Frangiotti. Rev. de H. Dalbosco. São Paulo: Paulus, 2007. 163p.

Confissões. 24. ed. Trad. de J. Oliveira Santos e A. Ambrósio de Pina. Petrópolis: Vozes, 2009. 376p.

BARDY, Gustave. Saint Augustin: l'homme et l'oeuvre. 4. ed. Paris: Desclée de Brouwer, 1940. 528 p.

BROWN, Peter. Santo Agostinho: uma biografia. Trad. de Vera Ribeiro. Rio de Janeiro: Record, 2005. 669 p.

BURGER, J-D. Saint Augustin. Neuchatel: Éditions de la Baconnière, 1948. 240 p.

CAPANAGA, Victorino. Agustin de Hipona: maestro de la conversión cristiana. Madrid: La Editorial Catolica/BAC, 1974. 475 p. 1954. $210 \mathrm{p}$.

San Agustin (semblanza biografiaca). Madrid: Ediciones Studium,

EVANS, Gillian R. Agostinho sobre o mal. Trad. de João Rezende. São Paulo: Paulus, 1995. $270 \mathrm{p}$.

JOLIVET, Regis. San Agustin y el neoplationismocristiano. Trad. de G. Blanco ; 0. Iozzia ; M. Guirao ; J. Otero ; E. Pironio y J. Ogar. Buenos Aires: Ediciones C.E.P.A, 1932. 219 p.

MARROU, Henri-Irénée. Saint Augustin etlafin de lacultureantique. Paris: E. deBoccard, Éditeur, 1938. 620 p.

PAPINI, Giovanni. Santo Agostinho. Trad. de M.G. da Costa. Braga: Livraria Cruz, 1949. 275 p.

SCIACCA, Michele Federico. San. Agustín. Trad. de Ulpiano Álvarez Díez. Barcelona: Luis Miracle, Editor, 1955. Tomo 1, 495 p.

SOUZA, Josemar Jeremias Bandeira de. Vida feliz, na filosofia de Santo Agostinho. Josemar Jeremias Bandeira de Souza. João Pessoa: UFPB, 2006, p.12. Dissertação (Mestrado em Filosofia).

TESTARD, Maurice. Saint Augustin et cicéron I: Cicéron dans la formation et dans l'oeuvre de Saint Augustin. Paris: Études Augustiniennes, 1958a. 392 p.

Saint Augustin et Cicéron II: répertoire des textes. Paris: Études Augustiniennes, 1958a. $142 \mathrm{p}$. 